\title{
Analisis Beta Karoten dan Vitamin pada Kulit dan Daging Buah Pisang Tongka Langit (Musa Troglodytarum L.) di Kota Ambon
}

\section{(Beta Carotene and Vitamin Analysis on the Peel and Pulp of Tongka Langit Banana (Musa Troglodytarum L.) in Ambon Island)}

\author{
Owend Paul Letelay'), Adriana Hiariej ${ }^{1 *)}$ dan Anneke Pesik $^{1)}$ \\ 1) Jurusan Biologi FMIPA Universitas Pattimura, Jl.Ir. M.Putuhena Kampus Poka, Ambon \\ "email korespondensi: hiariejd@yahoo.com
}

\begin{abstract}
Banana Tongka Langit with fruit bunches soaring up has varied morphological characters including fruit size (long and short), fruit flesh color (yellow to orange) and different banana peel colors (yellow, yellowish orange, reddish orange, reddish brown, and brown) brownish orange) which indicates the presence of beta carotene content. The purpose of the study was to analyze the content of beta carotene and vitamins in the skin and flesh of the Tongka Langit banana using the High Performance Liquid Chromatography method. The results of the analysis of the highest beta carotene content in long fruit flesh is $65.33 \mathrm{mg} / 100$ and the lowest in short fruit meat is $22.31 \mathrm{mg} /$ $100 \mathrm{~g}$. The most vitamin A found in short fruit skin $2260.63 \mathrm{mg} / 100 \mathrm{~g}$ and long fruit skin has the lowest value. The highest value of Vitamin B content is found in long fruit peels at $0.11 \mathrm{mg} / 100 \mathrm{~g}$ and the lowest in long fruit flesh and short fruit peels at $0.09 \mathrm{mg} / 100 \mathrm{~g}$. The most vitamin $\mathrm{C}$ found in long fruit flesh is $28.48 \mathrm{mg} / 100 \mathrm{~g}$, and the lowest in long fruit skin is $11.99 \mathrm{mg} / 100 \mathrm{~g}$. The highest vitamin $\mathrm{E}$ was found in long fruit peels at $0.41 \mathrm{mg} / 100 \mathrm{~g}$ and the lowest was in short fruit flesh at $0.21 \mathrm{mg} / 100 \mathrm{~g}$, while vitamin D was not found in all samples.
\end{abstract}

Keywords: Beta Carotene, HPLC, Tongka Langit Banana

\begin{abstract}
ABSTRAK
Pisang Tongka Langit dengan tandan buah menjulang ke atas memiliki karakter morfologi yang bervariasi diantaranya ukuran buah (panjang dan pendek), warna daging buah (kuning sampai oranye) dan warna kulit pisang yang berbeda (kuning, oranye kekuningan, oranye kemerahan, merah kecoklatan, dan oranye kecoklatan) yang mengindikasikan adanya kandungan beta karoten. Tujuan penelitian untuk menganalisis kandungan beta karoten dan vitamin pada kulit dan daging buah pisang Tongka Langit menggunakan metode High Performance Liquid Chromatography. Hasil analisis kandungan beta karoten tertinggi pada daging buah panjang sebesar $65,33 \mathrm{mg} / 100$ dan terendah pada daging buah pendek $22,31 \mathrm{mg} / 100 \mathrm{~g}$. Vitamin A yang terbanyak terdapat pada kulit buah pendek 2260,63 mg/100g dan kulit buah panjang memiliki nilai yang paling rendah. Nilai kandungan Vitamin B yang tertinggi terdapat pada kulit buah panjang sebesar $0,11 \mathrm{mg} / 100 \mathrm{~g}$ dan yang terendah pada daging buah panjang dan kulit buah pendek sebesar $0,09 \mathrm{mg} / 100 \mathrm{~g}$. Vitamin C yang terbanyak terdapat pada daging buah panjang sebesar $28,48 \mathrm{mg} / 100 \mathrm{~g}$, dan yang terendah pada kulit buah panjang $11,99 \mathrm{mg} / 100 \mathrm{~g}$. Vitamin E yang tertinggi terdapat pada kulit buah panjang sebesar $0,41 \mathrm{mg} / 100 \mathrm{~g}$ dan yang terendah terdapat pada daging buah pendek sebesar $0,21 \mathrm{mg} / 100 \mathrm{~g}$, sedangkan vitamin D tidak ditemukan pada semua sampel.
\end{abstract}

Kata Kunci: Beta Karoten, HPLC, Pisang Tongka Langit. 


\section{PENDAHULUAN}

\section{Latar Belakang}

Pisang Tongka Langit (Musa troglodytarum L.) memiliki arah tandan buah menjulang ke atas sehingga berbeda dengan pisang yang lain. Karakter morfologi sangat bervariasi diantaranya bentuk, buah, dan warna daging buah (kuning sampai oranye). Selain itu warna kulit pisang yang berbeda diantaranya kuning, oranye kekuningan, oranye kemerahan, merah kecoklatan, dan oranye kecoklatan (Hiariej et al., 2015) yang mengindikasikan adanya kandungan beta karoten.

Beta karoten dalam tubuh manusia merupakan prekursor vitamin A yang mempengaruhi perkembangan embrio, pertumbuhan dan penglihatan (Berman et al., 2015). Dalam industri makanan, beta karoten digunakan sebagai pigmen oranye-merah dalam banyak produk, seperti minuman nonalkohol yang tidak diolah secara termal dengan rasa buah-buahan tropis, lemak yang bisa dimakan, keju, kue, dan es krim (Fratianni et al., 2010). Secara umum vitamin diklasifikasikan menjadi dua yaitu vitamin yang larut dalam air (vitamin B dan C) dan vitamin yang larut dalam lemak (vitamin $\mathrm{K}$, E, D dan A). Menurut Aslam et al., (2017) bahwa vitamin adalah nutrisi organik penting dalam makanan yang digunakan oleh sel-sel tubuh untuk pertumbuhan, perkembangan, pencegahan penyakit yang tepat seperti gangguan defisiensi, dan meningkatkan efisiensi sistem kekebalan tubuh.

HPLC (High Performance Liquid Chromatography) adalah suatu metode analisis yang memisahkan campuran menjadi komponen tunggal melalui interaksi senyawa, fase gerak cair dan fase diam inert. Interaksi antara fase gerak dan fase diam beragam dan tergantung pada jenis senyawa yang mengalami pemisahan. Hasil dari sistem analisis datanya adalah kromatogram. HPLC sangat efisien untuk pemisahan molekul dalam waktu singkat (Bayne \& Carlin, 2017). Oleh sebab itu penelitian ini menggunakan metode HPLC untuk mendapatkan data tentang jumlah kandungan beta karoten dan vitamin $\mathrm{A}, \mathrm{B}, \mathrm{C}, \mathrm{D}$, dan E pada kulit dan buah pisang Tongka Langit.

\section{Tujuan Penelitian}

Untuk menganalisis kandungan beta karoten, vitamin A, B, C, D dan E pada kulit dan daging buah pisang Tongka Langit sebagai acuan pengembangan produk konsumsi masyarakat Maluku.

\section{METODOLOGI PENELITIAN}

\section{Waktu dan Lokasi Penelitian}

Pengambilan sampel dan analisis HPLC dilakukan pada bulan Agustus 2019. Pisang Tongka Langit buah panjang dari desa Hukurila dan buah pendek dari desa Air Louw kota Ambon. Analisis HPLC sampel kulit dan daging buah pisang Tongka Langit dilakukan pada laboratorium pengujian Balai Besar Penelitian dan Pengembangan Pascapanen Pertanian Bogor.

\section{Alat}

Alat yang digunakan ialah ultrasonik waterbath, labu takar, pipet, ayakan, stirrer, erlenmeyer, blender, neraca analitik, sentrifuse, labu evaporator, corong pemisah, labu volumetrik dan komponen HPLC.

\section{Bahan}

Bahan yang digunakan adalah kulit dan daging buah pisang Tongka Langit, $\mathrm{NaCl}$, etanol, $\mathrm{KOH}$, 2-propanol, isopropanol, etil asetat, air dingin (es), n-hexan, asam asetat glasial, asam asetat 2\% (20 g asam asetat glasial dilarutkan dalam 1 liter akuades) metanol, pyrogallol, metaphosporic acid, 2,6 dichloroindophenol, acetyl acid, thiourea, dinitrophenilhidraze, asam sulfat, petroluem eter, dietil eter, enzim makatase, glass woll, ammonia, acetonitril, kertas saring whatman No.41, $\mathrm{Al}_{2} \mathrm{O}_{3}$, aquades, parafilm.

\section{Prosedur Analisis Beta Karoten}

Sampel sebanyak 1-10 g ditambahkan $\mathrm{NaCl} 1 \mathrm{~mL}$, kemudian tambahkan pyrogallol dalam etanol $30 \mathrm{~mL}$ kemudian dihomogenizer. Tambahkan $\mathrm{KOH} 3 \mathrm{~mL}$ inkubasi dalam waterbath $56^{\circ} \mathrm{C}$ selama 20 menit dan pindahkan kedalam wadah berisi air dingin ditambah es. Tambahkan $\mathrm{NaCl} 1 \%$ $23 \mathrm{~mL}$, 2-propanol $6 \mathrm{~mL}$ dan ethyl acetat: nhexan (1:9) sebanyak $15 \mathrm{~mL}$ (3x ulangan), aduk selama 10 menit kemudian disentrifuse dengan kecepatan $3000 \mathrm{rpm}$ selama 5 menit. 
Ambil bagian atas kemudian masukan ke dalam labu evaporator $100 \mathrm{ml}$ (dievaporasi $40^{\circ} \mathrm{C}$ ) bilas dengan etanol 99,5\%. Sampel dimasukan kedalam labu takar $5 \mathrm{~mL}$ dengan etanol 99,5\% kemudian dimasukan ke HPLC sebanyak $20 \mu \mathrm{L}$ selama 8 menit. Output pemisahan campuran dihasilkan dalam bentuk kromatogram pada rekorder.

\section{Prosedur Analisis Vitamin A}

Sampel sebanyak $5 \mathrm{~g}$ ditambahkan $25 \mathrm{~mL}$ etanol kemudian diultrasonik sampai larut dan tambahkan $15 \mathrm{~mL}$ reagent $\mathrm{A}$. Aduk hingga homogen kemudian bilas dengan sedikit aquades. Lalu ditutup dengan parafilm dan simpan semalaman diruang gelap. Setelah itu tera dengan aquades lalu aduk. Saring dengan kertas saring whatman no. 41. Filtrat $(25 \mathrm{~mL})$ diambil dengan pipet $5.0 \mathrm{~mL}$ kemudian encerkan dengan acetonitril lalu kocok dengan ultrasonic bath 40'. Lewatkan ke dalam kolom berisi Glass woll dan $\mathrm{Al}_{2} \mathrm{O}_{3}$ dan filtrat siap diinjeksikan ke HPLC. Output pemisahan campuran dihasilkan dalam bentuk kromatogram pada rekorder.

\section{Prosedur Analisis Vitamin B}

Sampel digiling dan di ayak dengan ayakan 40 mesh. Kemudian ditimbang 0,5 g $2 \mathrm{~g}$ dan dimasukan ke dalam $100 \mathrm{~mL}$ labu volumetrik, lalu tambahkan $60 \mathrm{~mL}$ asam asetat $2 \%$, kemudian panaskan selama 20 menit dalam waterbath kemudian diultrasonik selama 5 menit. Setelah didinginkan, tambahkan $25 \mathrm{~mL}$ metanol kemudian larutan diimpitkan menggunakan asam asetat $2 \%$. Kemudian larutan disentrifuse dan supernatan dipisahkan untuk dinjeksikan ke HPLC. Output pemisahan campuran dihasilkan dalam bentuk kromatogram pada rekorder.

\section{Prosedur Analisis Vitamin C}

Sampel sebanyak $10 \mathrm{~g}$ ditambahkan metaphosporic acid 5\% w/v $50-60 \mathrm{ml}$ kemudian di homogenizer. Sampel dimasukan ke dalam labu takar $100 \mathrm{ml}$ dengan metaphosporic acid 5\% w/v lalu disimpan semalaman dalam lemari pendingin. Ambil 5 $\mathrm{mL}$ sampel standard lalu tambahkan 0,2 \% w/v DCP (2,6 Dichloroindophenol) 2-3 tetes (warna konstan). Tambahkan 0,2 \% w/v Thiourea dalam $5 \mathrm{ml}$ metaphosporic acid 5\% w/v kemudian tambahkan $2 \%$ w/v DNPH
(Dinitrophenilhidraze) dalam asam sulfat $9 \mathrm{~N}$ $1 \mathrm{~mL}$. Inkubasi ke dalam waterbath $50^{\circ} \mathrm{C}$ selama 90 menit lalu didinginkan dan tambahkan acetyl acid $5 \mathrm{~mL}$ kemudian di aduk selama 1 jam. Sentrifuse dengan kecepatan 3000rpm selama 5 menit kemudian dinjeksikan ke HPLC sebanyak $10 \mu \mathrm{L}$ selama 5-6 menit. Output pemisahan campuran dihasilkan dalam bentuk kromatogram pada rekorder.

\section{Prosedur Analisis Vitamin D}

Sampel sebanyak $100 \mathrm{~g}$ ditambahkan $1 \mathrm{~g}$ asam askorbat dan $40 \mathrm{~mL}$ etanol kemudian aduk sampai merata. Tambahkan $10 \mathrm{~mL} \mathrm{KOH}$ $60 \%$, distirer selama 30 menit, kemudian tambahkan kembali etanol $10 \mathrm{~mL}$. Simpan ditempat gelap selama satu malam. Larutan di stirrer kembali selama 30 menit sambil ditambahkan $50 \mathrm{~mL}$ campuran petroleum eter: dietil eter (1:1). Larutan sampel dipisahkan ke corong pemisah dan erlenmeyer, dibilas dengan air suling kemudian aduk selama 2 menit. Biarkan larutan tersebut terpisah bagian atas di tampung dalam labu kemudian aduk yang lain, bagian bawah ditambahkan kembali $30 \mathrm{~mL}$ campuran petroleum eter: dietil eter (1:1) aduk selama 2 menit, kemudian bagian atas dicampur dengan sampel. Larutan sampel dievaporasi sampai kering, kemudian diencerkan 2-5 mL dengan propanol dan untuk diinjeksikan ke HPLC. Output pemisahan campuran dihasilkan dalam bentuk kromatogram pada rekorder.

\section{Prosedur Analisis Vitamin E}

Sampel sebanyak $10 \mathrm{~g}$ dan dimasukan kedalam labu takar $200 \mathrm{~mL}$. Tambahkan 400 mg makatase dan $20 \mathrm{~mL}$ amonia 0,02\%, masukan ke dalam ultrasonik waterbath selama 20 menit pada suhu $65^{\circ} \mathrm{C}$. Campuran didinginkan pada suhu ruang, tambahkan etanol $100 \mathrm{~mL}$ dan masukan kembali ke ultrasonik selama 10 menit. Larutan ditambahkan etanol menjadi $200 \mathrm{~mL}$ lalu aduk, ambil sebagian larutan dan disentrifuse. Sampel diambil sebanyak $5 \mathrm{~mL}$ larutan jernih masukan kedalam labu takar $50 \mathrm{~mL}$, lalu injeksikan ke HPLC. Output pemisahan campuran dihasilkan dalam bentuk kromatogram pada rekorder. 


\section{Analisis Kualitatif dan Kuantitatif}

Tujuan dari analisis kualitatif adalah untuk mengidentifikasi puncak pada kromatogram dengan mencari kesamaan kromatogram sampel dan standard. Dengan membandingkan waktu retensi standard dan sampel pada kromatogram untuk diidentifikasi (Meyer, 2013). Sedangkan data kuantitatif diperoleh dengan Metode Baku Luar (External Standard Method). Membuat suatu baku atau standard yang mengandung senyawa-senyawa yang akan ditetapkan kadarnya. Idealnya jumlah standard sama dengan jumlah bahan yang akan dianalisis, kemudian membandingkan kromatogram standard dengan kromatogram sampel.

\section{HASIL DAN PEMBAHASAN}

Analisis beta karoten dan vitamin pada kulit dan daging buah panjang dan buah pendek pisang tongka langit ditampilkan dalam bentuk kromatogram (Gambar 1-5).

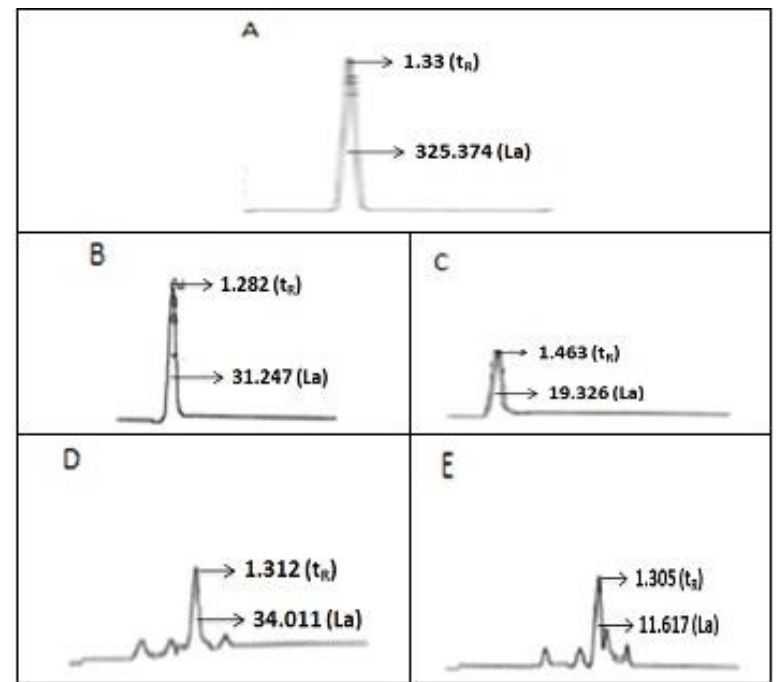

Gambar 1. Kromatogram beta karoten sampel kulit dan daging buah pisang Tongka Langit dengan waktu retensi $\left(t_{R}\right)$ dan luas area $(\mathrm{La})$ yang berbeda. (a). Standard beta karoten; (b). Kulit buah panjang; (c). Kulit buah pendek; (d). Daging buah panjang; (e). Daging buah pendek.

Hasil analisis pada Gambar 1 menunjukkan bahwa waktu retensi standard beta karoten adalah 1.33 menit dengan luas area sebesar 325.374. Waktu retensi beta karoten pada kulit buah panjang 1.282 menit dengan luas area sebesar 31.247 sedangkan pada kulit buah pendek sebesar 19.326 dengan waktu retensi 1.463 . Waktu retensi beta karoten pada daging buah panjang adalah 1.312 menit dan luas area sebesar 34.011 dan pada daging buah pendek waktu retensi adalah 1.305 menit dengan luas area sebesar 11.617. Hasil dari kromatogram sampel dibandingkan dengan kromatogram standard. Luas area yang didapat dihitung kosentrasinya menggunakan perhitungan eksternal standard. Hasil penelitian menunjukan bahwa waktu retensi pada kulit dan daging buah pendek lebih lama dari kulit dan daging buah panjang tetapi tidak memberikan pengaruh pada luas area beta karoten kulit dan daging buah pendek. Seluruh waktu retensi beta karoten pada sampel kulit dan daging buah panjang dan buah pendek. Waktu retensi yang terkecil pada kulit buah panjang yaitu 1.282 menit. Hal ini berarti bahwa beta karoten pada sampel kulit buah panjang lebih cepat terelusi pada detektor. Kromatogram vitamin A sampel kulit dan daging buah pisang Tongka Langit buah panjang dan pendek dengan waktu retensi $\left(t_{R}\right)$ dan luas area yang berbeda dapat dilihat pada Gambar 2.

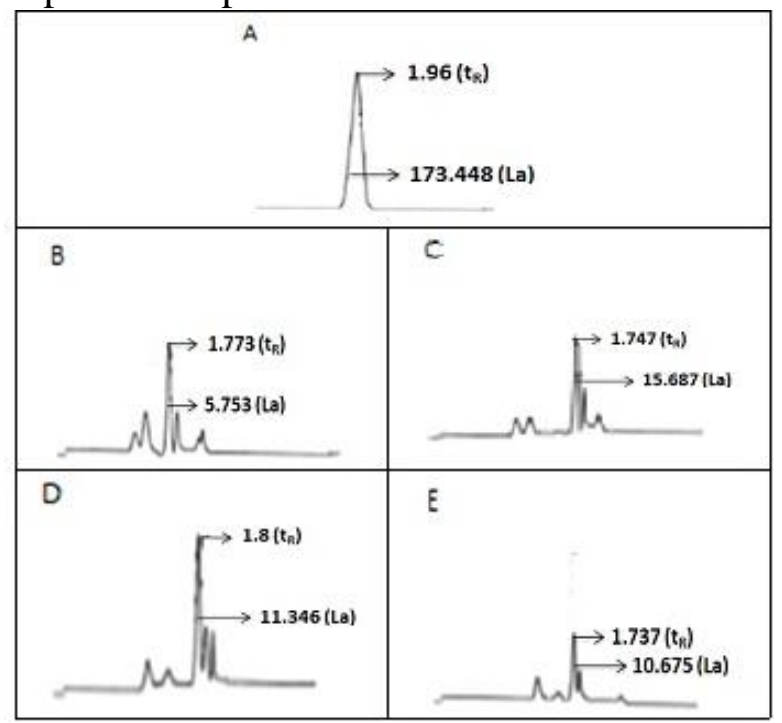

Gambar 2. Kromatogram vitamin A sampel kulit dan daging buah pisang Tongka Langit dengan waktu retensi $\left(t_{R}\right)$ dan luas area yang berbeda (a). Standard vitamin A; (b). Kulit buah panjang; (c). Kulit buah pendek; (d). Daging buah panjang; (e). Daging buah pendek. 
Berdasarkan hasil pada Gambar 2 terlihat bahwa waktu retensi standard vitamin A adalah 1.96 menit dan luas area 173.448. Luas area vitamin A pada kulit buah pendek lebih besar dari pada luas area pada kulit buah panjang. Hal ini dapat dilihat pada luas area kulit buah pendek sebesar 15.687 dengan waktu retensi 1.747 menit, sedangkan luas area pada kulit buah panjang sebesar 5.753 dengan waktu retensi 1.773 menit. Pada daging buah, luas area vitamin A daging buah panjang lebih besar yaitu 11.346 dengan waktu retensi 1.8 menit, dibandingkan dengan luas area daging buah pendek yaitu 10.675 dengan waktu retensi 1.737 menit. Dari waktu retensi vitamin A sampel kulit dan daging buah panjang dan buah pendek. Waktu retensi yang terkecil adalah pada sampel daging buah pendek yaitu 1.737 menit. Hal ini berarti beta karoten pada sampel daging buah pendek lebih cepat terelusi dari sampel lain. Secara keseluruhan, waktu retensi tidak berpengaruh terhadap luas area. Kromatogram vitamin B sampel kulit dan daging buah pisang Tongka Langit dengan waktu retensi $\left(t_{R}\right)$ dan luas area yang berbeda dapat dilihat pada Gambar 3.

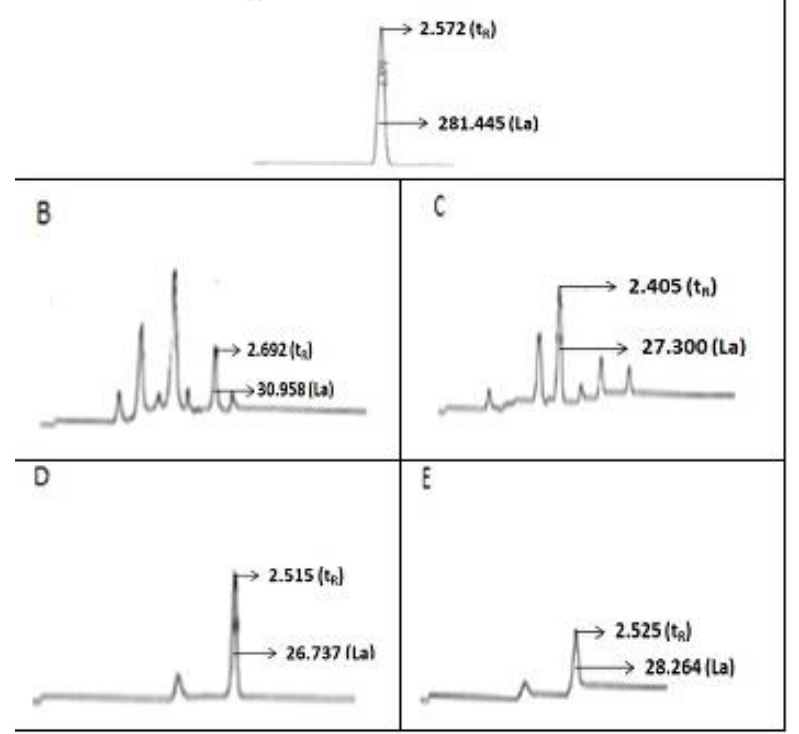

Gambar 3. Kromatogram vitamin B sampel kulit dan daging buah pisang Tongka Langit dengan waktu retensi $\left(t_{R}\right)$ dan luas area yang berbeda (a). standard vitamin B; (b). Kulit buah panjang; (c). Kulit buah pendek; (d). Daging buah panjang; (e). Daging buah pendek.
Berdasarkan data kromatogram pada Gambar 3 menunjukkan bahwa standard vitamin B memiliki waktu retensi 2.572 menit dengan luas area 281.445. Sedangkan waktu retensi vitamin B pada kulit buah panjang adalah 2.692 menit dan luas area sebesar 30.958 lebih besar dari luas area pada kulit buah pendek dimana luas area sebesar 27.300 dengan waktu retensi adalah 2.405 menit. Waktu retensi vitamin B pada daging buah panjang adalah 2.513 menit dengan luas area 26.737 sedangkan waktu retensi pada daging buah pendek adalah 2.525 menit dan luas area sebesar 28.264.

Waktu retensi yang terkecil terdapat pada sampel kulit buah pendek yaitu 2.405 menit. Waktu retensi vitamin $\mathrm{B}$ yang terkecil menunjukan bahwa vitamin B pada sampel kulit buah pendek lebih cepat terelusi atau terdeteksi pada detektor. Kromatogram vitamin C sampel kulit dan daging buah pisang Tongka Langit dengan waktu retensi $\left(t_{R}\right)$ dan luas area yang berbeda dapat dilihat pada Gambar 4.

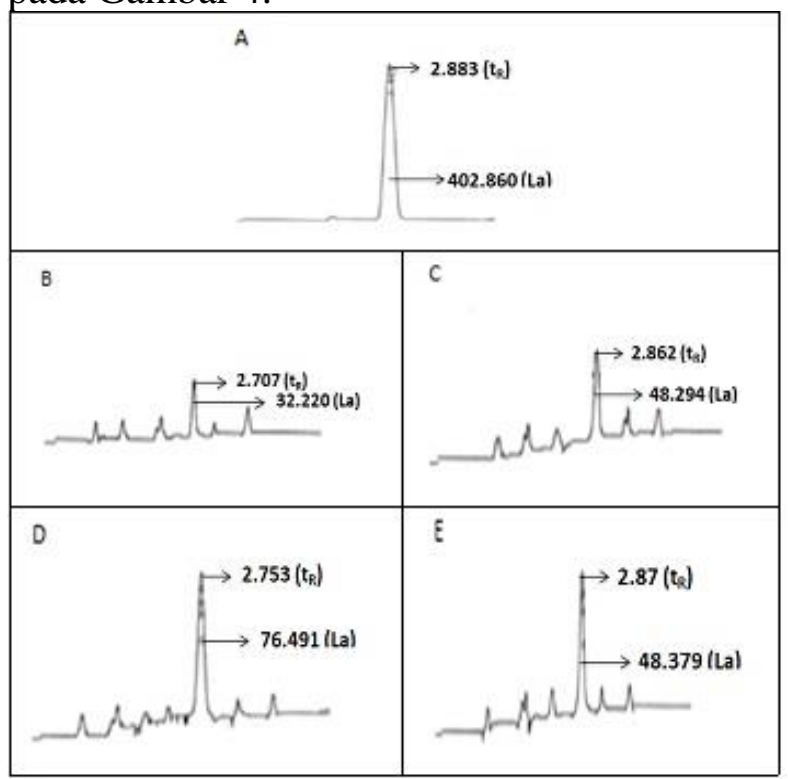

Gambar 4. Kromatogram vitamin C sampel kulit dan daging buah pisang Tongka Langit dengan waktu retensi $\left(t_{R}\right)$ dan luas area yang berbeda (a). Standard vitamin C; (b). Kulit buah panjang; (c). Kulit buah pendek; (d). Daging buah panjang; (e). Daging buah pendek. 
Berdasarkan hasil analisis pada Gambar 4 terlihat bahwa waktu retensi standard vitamin $\mathrm{C}$ adalah 2.883 menit dengan luas area sebesar 402.860. Waktu retensi pada vitamin C kulit buah pendek adalah 2.862 menit dengan luas area 48.294 lebih besar jika dibandingkan dengan luas area pada kulit buah panjang, yaitu sebesar 32.220 dengan waktu retensi 2.707 menit. Sedangkan luas area vitamin $\mathrm{C}$ daging buah panjang yaitu 76.491 dengan waktu retensi 2.753 menit lebih besar jika dibandingkan dengan daging buah pendek yaitu luas area sebesar 48.379 dengan waktu retensi adalah 2.87 menit. Kromatogram vitamin E sampel kulit dan daging buah pisang Tongka Langit buah panjang dan pendek dengan waktu retensi $\left(t_{R}\right)$ dan luas area yang berbeda dapat dilihat pada Gambar 5.

Waktu retensi vitamin C yang terkecil terdapat pada sampel kulit buah panjang yaitu 2.707 menit. Waktu rentensi vitamin $\mathrm{C}$ yang terkecil menunjukan bahwa vitamin $\mathrm{C}$ pada sampel kulit buah panjang lebih cepat terelusi atau terdeteksi pada detektor. Secara keseluruhan, waktu retensi vitamin $\mathrm{C}$ sampel kulit dan daging buah panjang dan buah pendek tidak berpengaruh terhadap besarnya luas area pada puncak kromatogram. Kromatogram vitamin E sampel kulit dan daging buah pisang Tongka Langit dengan waktu retensi $\left(t_{R}\right)$ dan luas area yang berbeda dapat dilihat pada Gambar 5.

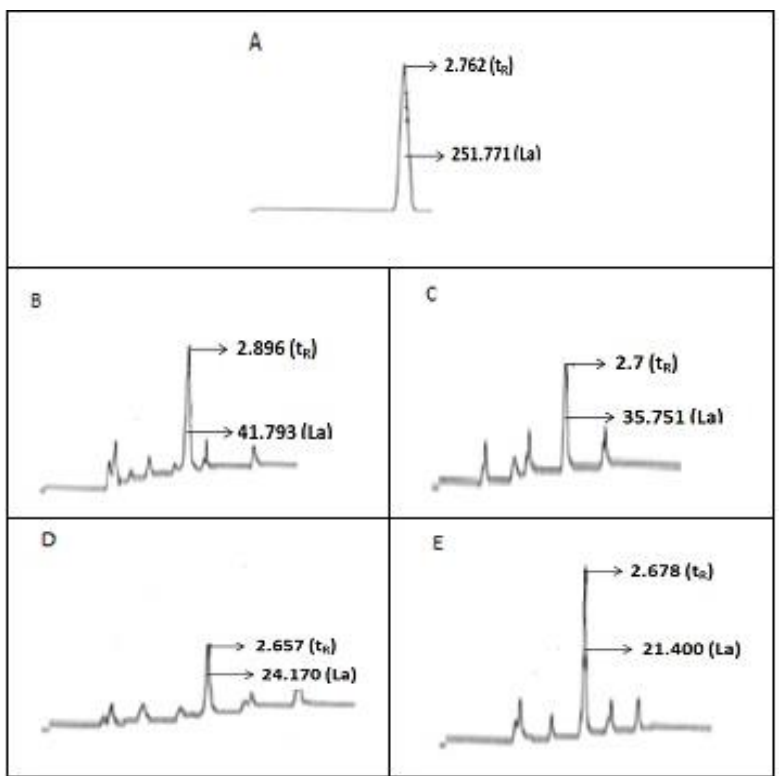

Gambar 5. Kromatogram vitamin E sampel kulit dan daging buah pisang Tongka Langit dengan waktu retensi $\left(t_{R}\right)$ dan luas area yang berbeda (a). Standard vitamin E; (b). Kulit buah panjang; (c). Kulit buah pendek; (d). Daging buah panjang; (e). Daging buah pendek.

Berdasarkan hasil analisis pada Gambar 5 terlihat bahwa waktu retensi standard vitamin $\mathrm{E}$ adalah 2,762 menit dengan luas area sebesar 251.771. Luas area vitamin E pada kulit dan daging buah panjang lebih tinggi jika dibandingkan dengan luas area pada kulit dan daging buah pendek. Hal ini dapat dilihat pada kulit dan daging buah panjang memiliki luas area masing-masing sebesar 41.793 dengan waktu retensi 2.896 menit dan 24.170 dengan waktu retensi 2.657 menit. Sedangkan pada kulit dan daging buah pendek masing-masing sebesar 35.751 dengan waktu retensi 2.7 menit dan 21.400 dengan waktu retensi 2.678 menit.

Waktu retensi vitamin E yang terkecil terdapat pada sampel daging buah panjang yaitu 2.567 menit. Waktu retensi vitamin E yang terkecil menunjukan bahwa vitamin $\mathrm{E}$ pada sampel daging buah panjang lebih cepat terelusi atau terdeteksi pada detektor. Secara keseluruhan, waktu retensi vitamin E sampel kulit dan daging buah panjang dan buah pendek juga tidak berpengaruh terhadap besarnya luas area pada puncak kromatogram 
Kandungan beta karoten dan vitamin pada kulit dan daging buah pisang Tongka Langit dapat dilihat pada Tabel 1.

Tabel 1. Hasil analisis kandungan vitamin dan beta karoten pada kulit dan daging buah panjang dan pendek.

\begin{tabular}{ccccc}
\hline \multirow{2}{*}{ Parameter } & \multicolumn{2}{c}{ Buah Panjang } & \multicolumn{2}{c}{ Buah Pendek } \\
\cline { 2 - 5 } & Kulit Buah & Daging Buah & Kulit Buah & Daging Buah \\
\hline Beta karoten & 60,02 & 65,33 & 37.12 & 22,31 \\
mg/100g & 829,05 & 1635,05 & 2260,63 & 1538,36 \\
Vitamin A IU & 0,11 & 0,09 & 0,09 & 0,10 \\
Vitamin B mg/100g & 11,99 & 28,48 & 17,98 & 18,01 \\
Vitamin C mg/100g & - & - & - & - \\
Vitamin D mg/100g & 0,41 & 0,24 & 0,35 & 0,21 \\
Vitamin E mg/100g & & & & \\
\hline
\end{tabular}

Hasil analisis kandungan beta karoten dan vitamin (Tabel 1) terlihat bahwa nilai beta karoten dan vitamin A pada kulit buah panjang lebih rendah jika dibandingkan dengan nilai beta karoten dan vitamin A pada daging buah, sedangkan beta karoten dan vitamin A pada kulit buah pendek lebih tinggi dari daging buah pendek. Vitamin B pada kulit buah panjang lebih tinggi dari daging buah panjang, sedangkan vitamin B pada kulit buah pendek lebih rendah dari daging buahnya. Vitamin C pada sampel kulit buah panjang dan pendek lebih tinggi jika dibandingkan dengan vitamin $\mathrm{C}$ pada sampel daging buah pendek. Vitamin E pada kulit buah panjang dan buah pendek lebih besar dari daging buahnya, sedangkan vitamin $\mathrm{D}$ pada kulit dan daging buah panjang dan pendek tidak ditemukan.

Nilai kandungan beta karoten dan vitamin pada kulit dan daging buah panjang dan pendek dapat dilihat pada Gambar 6 dan 7 .

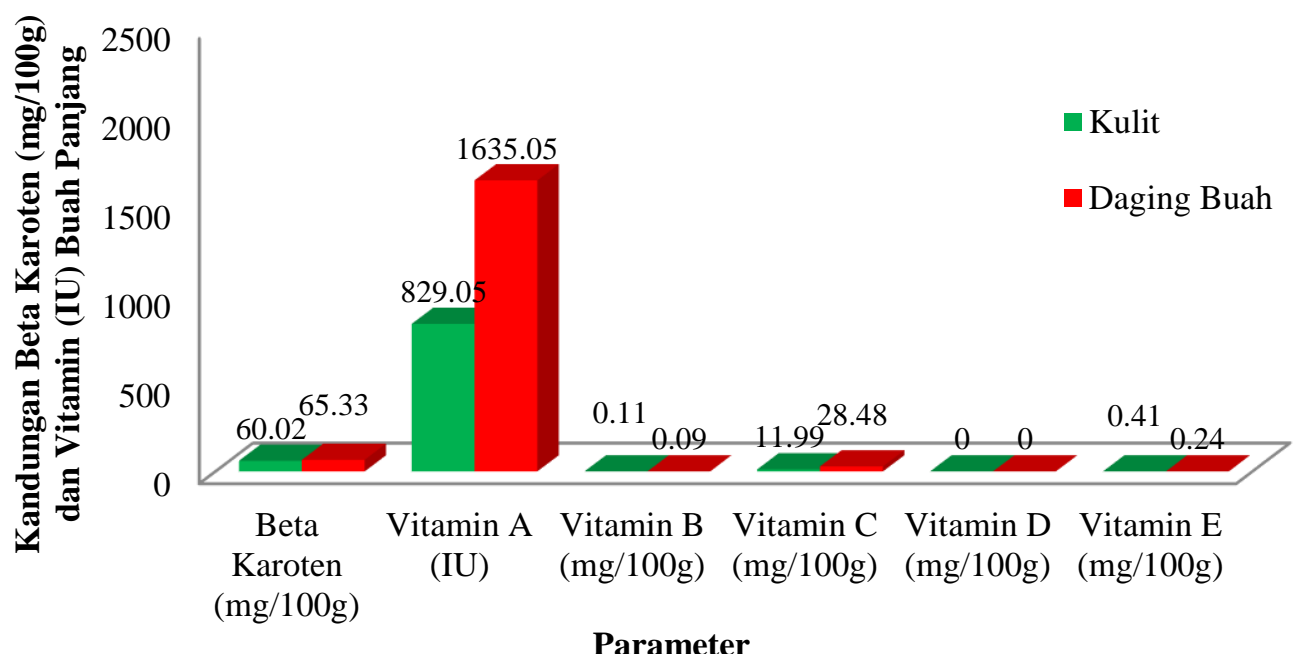

\section{Parameter}

Gambar 6. Histogram kandungan beta karoten dan vitamin pada kulit dan daging buah panjang.

Kandungan vitamin A pada kulit dan daging buah sangat tinggi bila dibandingkan dengan kandungan beta karoten dan vitamin B, C, dan E. Vitamin D dalam hasil analisis tidak ditemukan (Gambar 6). Gambar 7 menjelaskan tentang kandungan beta karoten dan vitamin pada kulit dan daging buah pendek. Kandungan vitamin A pada kulit dan daging buah sangat tinggi bila dibandingkan dengan kandungan beta karoten dan vitamin $\mathrm{B}$, C, dan $\mathrm{E}$ sedangkan vitamin $\mathrm{D}$ tidak ditemukan. 


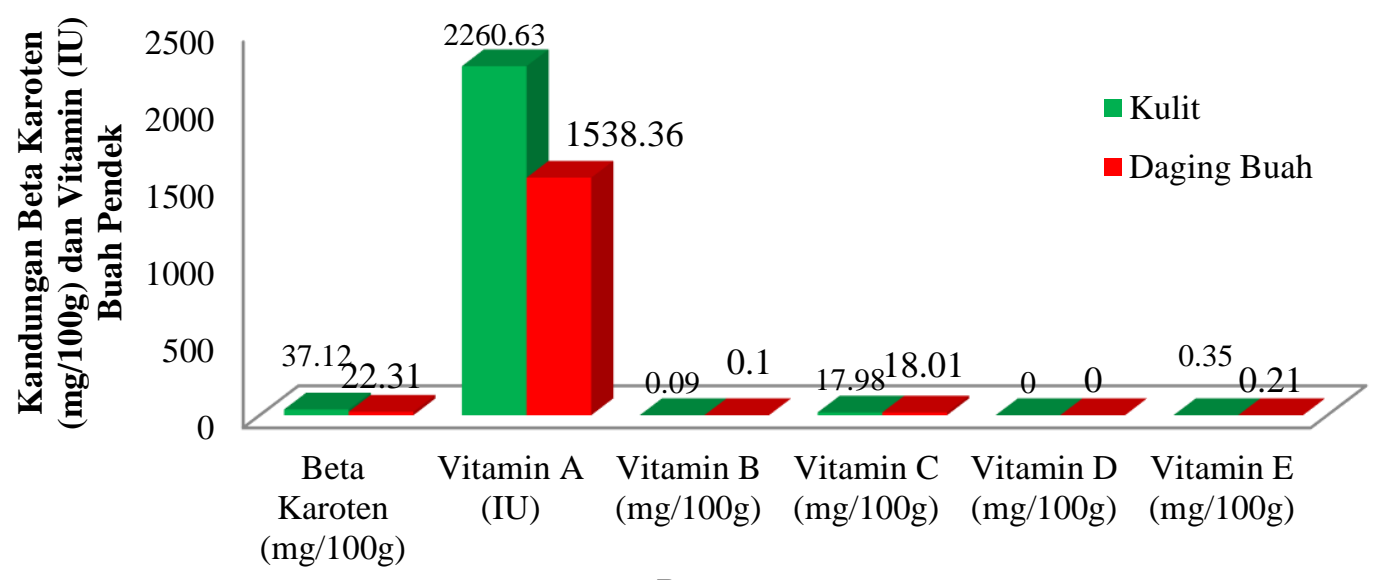

\section{Parameter}

Gambar 7. Histogram kandungan beta karoten dan vitamin pada kulit dan daging buah pendek

Analisis kualitatif dalam pemisahan campuran senyawa menggunakan HPLC yaitu membandingkan kromatogram standard dengan kromatogram sampel dengan mencari kesamaan waktu retensi $\left(t_{R}\right)$ dari keduanya. Waktu retensi $\left(t_{R}\right)$ adalah waktu yang diperlukan suatu senyawa untuk berpindah dari injektor ke detektor (Bayne and Carlin, 2010). Sedangkan luas area menggambarkan nilai lebar dan tinggi puncak suatu komponen pada kromatogram.

Berdasarkan hasil penelitian dapat dilihat bahwa kandungan beta karoten kulit dan daging buah panjang lebih tinggi jika dibandingkan dengan kulit dan daging buah pendek. Nilai beta karoten pada kulit buah panjang sebesar $60,02 \mathrm{mg} / 100 \mathrm{~g}$ dan daging buah $65,33 \mathrm{mg} / 100 \mathrm{~g}$ sedangkan pada buah pendek, kandungan beta karoten pada kulit buah sebesar $37,12 \mathrm{mg} / 100 \mathrm{~g}$ dan daging buah $22,31 \mathrm{mg} / 100 \mathrm{~g}$.

Beta karoten adalah senyawa karotenoid yang bertanggung jawab atas warna kuning, merah hingga oranye pada buah dan sayuran. Pada tubuh beta karoten memiliki sifat antioksidan yang dapat menghancurkan radikal bebas penyebab kerusakan sel, mencegah kanker, serta menurunkan resiko terjadinya penyakit jantung (Khan et al., 2014). Penelitian yang dilakukan Shen et al., (2019) mengamati sel kulit dan daging buah pepaya. Mereka menemukan perbedaan bentuk kromoplas antara kulit dan daging buah pepaya. Kromoplas adalah organel sel tumbuhan yang bertanggung jawab atas pigmen karotenoid. Kromoplas terdapat pada organ buah, bunga, akar, dan daun yang telah menua. Hasil penelitian ini menggambarkan perbedaan komposisi karotenoid antara kulit dan daging buah.

Hasil penelitian menunjukkan bahwa kandungan vitamin A pada kulit buah panjang rendah jika dibandingkan dengan daging buah (Tabel 1). Nilai vitamin A pada kulit buah panjang sebesar 829,05 IU dan daging buah 1635,05 IU, sedangkan pada kulit buah pendek sebesar 2260,63 IU lebih besar dibandingkan daging buah yaitu 1538,36 IU. Vitamin A dihasilkan melalui aksi enzim beta karoten 15,15'-monooksigenase (BCM01) di hati dan usus kecil. Vitamin A memiliki fungsi penting dalam tubuh diantaranya berfungsi untuk penglihatan, karena merupakan prekursor pembentukan 11-cisretinal (Palczewski, 2012).

Nilai vitamin B pada kulit buah panjang lebih tinggi dari daging buahnya yaitu sebesar $0,11 \mathrm{mg} / 100 \mathrm{~g}$ dan pada daging buah sebesar $0,09 \mathrm{mg} / 100 \mathrm{~g}$, sedangkan nilai vitamin $\mathrm{B}$ pada kulit buah pendek sebesar $0,09 \mathrm{mg} / 100 \mathrm{~g}$ lebih rendah dibandingkan daging buahnya sebesar 0,10 mg/100g. Menurut Kaur (2015) vitamin B adalah vitamin yang penting dalam menjaga kesehatan sistem saraf, kulit, mata, rambut, hati, fungsi otak, bentuk otot dan saluran pencernaan. Vitamin ini bersama membantu melepaskan enzim dari makanan, mempromosikan metabolisme yang tepat, memberikan oksigen yang banyak pada sel dan detoksifikasi organ. Meskipun nilai vitamin B pada kulit dan buah panjang dan pendek pisang tongka langit sangat kecil, 
namun dapat memberikan manfaat bagi tubuh bila dikonsumsi.

Kandungan vitamin $\mathrm{C}$ pada kulit buah panjang dan pendek lebih rendah bila dibandingkan vitamin $\mathrm{C}$ pada daging buah panjang dan pendek yaitu pada kulit buah panjang dan pendek berturut-turut sebesar $11,99 \mathrm{mg} / 100 \mathrm{~g}$ dan 17,98 , sedangkan pada daging buah panjang dan pendek berturutturut sebesar $28,48 \mathrm{mg} / 100 \mathrm{~g}$ dan 18,01 $\mathrm{mg} / 100 \mathrm{~g}$. Pada tubuh manusia vitamin $\mathrm{C}$ berperan dalam sintesis kolagen, karnitin, dan biosintesis neurotransmitter. Mengonsumsi makanan yang mengandung vitamin $\mathrm{C}$ membantu tubuh dalam fungsi detoksifikasi organ hati, melindungi darah untuk memutuskan infeksi, meningkatkan daya tahan tubuh, dan bekerja sebagai agen pereduksi untuk memadamkan radikal bebas, dan sifat antioksidan yang dikaitkan dengan pencegahan kanker (Sharma et al., 2014).

Kandungan vitamin E pada kulit buah panjang secara berturut-turut adalah 0,41 $\mathrm{mg} / 100 \mathrm{~g}$ dan daging buah $0,24 \mathrm{mg} / 100 \mathrm{~g}$, memiliki nilai lebih tinggi jika dibandingkan dengan kulit dan daging buah pendek. Vitamin E pada kulit dan daging buah pendek secara berturut-turut yaitu sebesar 0,35 $\mathrm{mg} / 100 \mathrm{~g}$ dan $0,21 \mathrm{mg} / 100 \mathrm{~g}$. Vitamin $\mathrm{E}$ memiliki manfaat yaitu sebagai anti kanker, mencegah anemia karena kerusakan oksidatif pada sel darah merah, mencegah retinopati (kerusakan retina mata) dan mengatasi infertilitas atau kemandulan pada pria (Rizvi et al., 2014).

Vitamin D tidak terdapat pada kulit dan daging buah panjang dan buah pendek karena vitamin $\mathrm{D}$ hanya terdapat pada beberapa tanaman tertentu dari famili Solanaceae dan Winteraceae (Tasmannia lanceolata) dalam bentuk cholecalciferol (vitamin $\mathrm{D}_{3}$ ) (Black et al., 2017). Menurut Jäpelt \& Jakobsen (2013) vitamin D terbagi atas dua bentuk utama yaitu cholecalciferol $\left(\mathrm{D}_{3}\right)$ dan ergocalciferol (vitamin $\mathrm{D}_{2}$ ). Vitamin $\mathrm{D}_{2}$ dihasilkan oleh ragi dan jamur sedangkan vitamin $\mathrm{D}_{3}$ hanya pada tanaman yang terpapar radiasi sinar UV contohnya famili Solanaceae yang memiliki metabolit vitamin $\mathrm{D}_{3}$ lebih tinggi dibandingkan tanaman yang tidak mendapat radiasi sinar UV.
Produksi suatu senyawa oleh tumbuhtumbuhan sangat dipengaruhi oleh berbagai faktor diantaranya variasi fisiologi, perkembangan organ, keadaan lingkungan, iklim, hama dan penyakit, polusi, faktor edafik (tanah), evolusi dan faktor genetik. Evolusi gen atau terjadinya mutasi pada tumbuhan sangat mempengaruhi fungsi enzimatik yang berkaitan dengan produksi senyawa pada tumbuh-tumbuhan (Figueiredo et al., 2008).

\section{KESIMPULAN}

Kandungan beta karoten tertinggi terdapat pada daging buah panjang sebesar $65,33 \mathrm{mg} / 100 \mathrm{~g}$ dan terendah pada daging buah pendek 22,31 mg/100 g. Kandungan vitamin A tertinggi terdapat pada kulit buah pendek 2260,63 IU dan kulit buah panjang memiliki nilai yang paling rendah yaitu 829,05 IU. Nilai kandungan vitamin B yang tertinggi terdapat pada kulit buah panjang sebesar $0,11 \mathrm{mg} / 100 \mathrm{~g}$ dan terendah di daging buah panjang dan kulit buah pendek sebesar $0,09 \mathrm{mg} / 100 \mathrm{~g}$. Vitamin C yang terbanyak terdapat pada daging buah panjang sebesar $28,48 \mathrm{mg} / 100 \mathrm{~g}$, dan terendah pada kulit buah panjang $11,99 \mathrm{mg} / 100 \mathrm{~g}$. Vitamin E yang tertinggi terdapat pada kulit buah panjang sebesar 0,41 mg/100 g dan terendah pada daging buah pendek sebesar $0,21 \mathrm{mg} / 100 \mathrm{~g}$, sedangkan vitamin D tidak terdapat pada kulit dan buah pisang Tongka Langit.

\section{UCAPAN TERIMA KASIH}

Terima kasih kepada Universitas Pattimura melalui dana BOPTN tahun 2019 yang telah membantu untuk pengambilan sampel penelitian.

\section{DAFTAR PUSTAKA}

Aslam, M., Majeed, S., Aslam, S., \& Irfan, J. (2017). Vitamins: Key role players in boosting up immune response-A mini review. Vitam. Miner, 6, 153.

Bayne, S., \& Carlin, M. (2017). Forensic applications of high performance liquid chromatography: CRC Press. 
Berman, J., Zorrilla-López, U., Farré, G., Zhu, C., Sandmann, G., Twyman, R. M., Christou, P. (2015). Nutritionally important carotenoids as consumer products. Phytochemistry Reviews, 14(5), 727-743.

Black, L. J., Lucas, R. M., Sherriff, J. L., Björn, L. O., \& Bornman, J. F. (2017). In pursuit of vitamin $\mathrm{D}$ in plants. Nutrients, 9(2), 136.

Figueiredo, A. C., Barroso, J. G., Pedro, L. G., \& Scheffer, J. J. (2008). Factors affecting secondary metabolite production in plants: volatile components and essential oils. Flavour and Fragrance journal, 23(4), 213-226.

Fratianni, A., Cinquanta, L., \& Panfili, G. (2010). Degradation of carotenoids in orange juice during microwave heating. LWT-Food Science and Technology, 43(6), 867-871.

Hiariej, A., Arumingtyas, E. L., Widoretno, W., \& Azrianingsih, R. (2015). Phenotypic Variation of Fei Banana (Musa Troglodytarum L.) Originated from Maluku Islands. Research Journal of Pharmaceutical, Biological and Chemical Sciences, 6(2), 6.

Jäpelt, R. B., \& Jakobsen, J. (2013). Vitamin $\mathrm{D}$ in plants: a review of occurrence, analysis, and biosynthesis. Frontiers in plant science, 4, 136.

Kaur, A. (2015). Biological Functions of Vitamin B complex and effects on human health in both excess and deficiency levels. PharmaTutor, 3(11), 40-47.

Khan, M., Iqubal, A., Joshi, A., \& Ajai, K. (2014). Role of antioxidants in prevention of cancer: A review. International Journal of Current Research and Review, 6(9), 80.

Meyer, V. R. (2013). Practical highperformance liquid chromatography: John Wiley \& Sons.
Rizvi, S., Raza, S. T., Faizal Ahmed, A. A., Abbas, S., \& Mahdi, F. (2014). The role of vitamin $\mathrm{E}$ in human health and some diseases. Sultan Qaboos University Medical Journal, 14(2), e157.

Sharma, P., Sharma, P. K., Mishra, V. B., \& Bhandari, A. (2014). Source, Chemistry, Metabolism, Physiological Function: Ascorbic Acid With Human Health. Journal of Drug Delivery and Therapeutics, 4(5), 74-78. 